two together in a Cod under the Earth, and shoot out a small Leaf above the surface of the Earth; these are the worst of all the sorts of Beans, and yet they are eaten by several " (ANew and Accurate Description of the Coast of Guinea, etc. . . . Written originally in Dutch by Wm. Bosman. . . . And now faithfully done into English, London, 1705, p. 301). From gobbe to goober is not far, and the object named is the same, beyond a doubt. The origin of buccra ('white man') is not clear; but in Haussa, buttra means 'master.' I would appeal to those acquainted with the negro dialects to publish short lists of words, such as those dealt with, which will be of great value in determining the ethnological relations of the ancestors of the present negro population of the United States.

Toronto, July 2.

A. F. Chamberlain.

\section{Object-Lessons in Oriental Faiths and Myths.}

A REMARKABLE collection will soon be opened to the world in Paris. The municipality has given a plot of ground that cost two hundred thousand dollars on the Avenue d'Jéna, and a large and beautiful stone structure has been erected on it by the state, under a law passed while the present president, Carnot, was finance minister. This law secures over three hundred thousand dollars for the erection of a building, and endows the establishment thus formed with a perpetual annuity of nine thousand dollars for purposes of maintenance. The glass cases for the collection are partly placed and filled, and the public will be admitted in a few months.

The collection is primarily intended to teach the history of the development, and the characteristics, of the Oriental religions. The importance of this study strikes us forcibly when we reflect that these forms of faith still deeply influence the daily lives of more than one-half of the human race, and that they have solaced and guided tens of thousands of millions of our fellow-creatures.

The originator and collector of this unique series of objects is the well-known student of Oriental languages, M. Etienne Emile Guimet, the son of a wealthy citizen of Lyons. He has spent more than twenty years of an active scholarly life in voyages to, and residences in, China, Japan, and other Asiatic lands, and has devoted several millions of francs from his large fortune to this work of public instruction. In his native town he is also known for his persistent and munificent efforts to secure high-class musical entertainments for the people; and, if his efforts are measured by the exquisite congregational singing that I recently heard in one of the Lyons churches, his efforts have been signally successful.

Yesterday I spent the morning with M. Guimet, examining the collections already in place. We first passed through two long halls, carefully arranged, and lighted from both sides with high windows, - halls, let me say, that would form admirable models for the future architects of the Metropolitan Museum. Here we found two comprehensive collections of pottery, - one from China and one from Japan, - each arranged geographically and historically, beginning, in the case of Japan, with the southern provinces, and ending with the northern. These most valuable gifts of $M$. Guimet, however, do not belong to my present subject.

From these halls we entered the lofty library, where are already placed twelve thousand volumes of books and manuscripts containing official statements in the original tongues of the dogmas, creeds, and myths of all the important Oriental forms of belief. Thence we passed to an extensive hall, in which the Japanese religions are illustrated and classed.

Illustrations of the earliest form of the Shinto nature-worship begin the extensive series. First we have the round metal mirrors resting upon mimic waves of sculptured wood, that stood high in the temple to catch the earliest rays of the rising sun; then figures of the simply clad priests ; then the implements for making the primitive offering of fire and incense to the unembodied god. In order of time follow the paraphernalia of the Buddhist priests, who, crossing from Corea, brought with them their gorgeous ritual and imposed it upon the nation. Then we have innumerable figures of Buddha and attendant deities in gold, silver, bronze, lacquer, and clay, representing the ideas of the important contending sects into which Buddhism was soon divided through the agency of sacerdotal ingenuity.

In the middle of the hall, under the skylight, is a representation of the interior of a Japanese temple of the first class, with original images of all the gods before whom worship is usually conducted. Here we may see, how, in the imagination of the Japanese (the sacred Buddha sends forth four great agencies that save men through persuasion), they are shown to the popular eye in the form of golden figures of prophets in silken robes; and also how four other emanations from Buddha, symbolical of darkness, compel men to do right through fear, shown as carved images of black devils with gnashing teeth.

Beyond this group are series of cases containing thousands of objects explaining Japanese myths, lives of saints, and the stories told about their sacred people and places. Another extensive hall contains a series of figures and other objects elucidating the forms of belief, the myths, and the folk-lore of China. In another the Greek mythology is systematized, in another the Roman, in another the Egyptian. One of the most interesting cases is that containing. original images from many places in the countries and islands bordered by the Mediterranean, showing the various steps by which the Egyptian gods were accepted and adopted under new names successively by the Greeks and by the Romans. The rooms containing the collections from the western lands are as yet but partly arranged. Enough can be seen, however, to show how important and complete the series of objects must be, - enough to show that the world furnishes no other collection of the kind nearly so large, or so well prepared for the serious study of the development of Oriental and ancient civilization.

M. Guimet declared that he had no theory to support in forming his museum. He has excluded the Christian and the Hebrew forms of worship from his scientific treatment, and has confined himself to those lands where religion dawned upon mankind, and where great faiths that dominated extensive territories were developed. He simply presented the authentic documents and the authorized symbols for the use of the scholar.

Paris, June 20.

L.

\section{An Army of Myriopods.}

I am in receipt of a letter, bearing the date July 6, I888, from $\mathrm{Mr}$. W. H. Cleaver, East Bethlehem, Penn., in which he states that the 'worms,' specimens of which he sends, are at the present time very abundant in his neighborhood.

To quote from the letter, "they are travelling eastward in countless millions. They travel at night or in the cool of the morning and evening. They camp during the day by getting under sods, boards, stones, or any thing to protect them from the heat of the sun. In some places during the day they are piled up in great numbers. They do not seem to destroy any thing on their journey, but go harmlessly along. Fowls will not eat them, and birds do not appear to molest them."

The specimens which accompany the letter are, I think, the common Polydesmus erythropygus. In the absence of any complete systematic work on the Myriopoda, I am not able to identify the species with absolute certainty. The species is very common in this vicinity, but I have never before heard of its occurrence in such numbers as reported by Mr. Cleaver. EDwin LinTon.

Washington and Jefferson College, Washington, Penn., July 7.

\section{The Old South Work.}

You credit me, in your last number, with instituting the lectures in Chicago, like our 'Old South' lectures here in Boston. That credit does not belong to me. I have for some years been concerned in the direction of the 'Old South Work' in Boston, which is so liberally sustained by Mrs. Hemenway; and recently I gave the opening lecture in the Chicago course. But the credit of instituting the work in Chicago belongs to Mr. H. H. Belfield, the principal of the Manual-Training School in that city. He has labored with rare devotion and energy to establish these 'Old South' lectures in Chicago, and his success has certainly been very great. If every city had a man of equal patriotism and equal practical power, we should see much done to bring our young people up to higher ideas of citizenship, and to elevate the general political tone throughout the country.

Boston, July 9 .
EDWIN D. MEAD. 